\title{
Pemberian Tepung Kunyit (Curcuma longa) sebagai Pakan Tambahan Alami sebagai Upaya dalam Meningkatkan Produktivitas Sapi Peranakan Ongole
}

\section{The Adduction of Turmeric Flour (Curcuma longa) as a Botany Feed Additive to Productivity Improvement of Ongole Cross Cattle}

\author{
N. E. Wati* dan M. Suhadi \\ Fakultas Peternakan, Universitas Tulang Bawang, Lampung \\ Jl. Gajah Mada No.34, Kotabaru, Bandar Lampung - Indonesia \\ *Corresponding E-mail: novi.ekawati1990@gmail.com \\ (Diterima: 7 November 2020; Disetujui: 27 April 2021)
}

\begin{abstract}
ABSTRAK
Penambahan tepung kunyit sebagai feed aditif alami pada pakan dilakukan untuk meningkatkan produktivitas sapi pedaging. Tujuan penelitian adalah untuk mengevaluasi pemberian tepung kunyit pada pakan terhadap produktivitas sapi peranakan Ongole. Penelitian dilaksanakan di PGS. Joe Cipir Desa Jati Indah, Kecamatan Tanjung Bintang, Kabupaten Lampung Selatan. Penelitian menggunakan Rancangan Acak Kelompok dengan materi 9 ekor sapi peranakan Ongole jantan berumur $\pm 1,5$ tahun yang dikelompokkan menjadi 3 kelompok yaitu sapi dengan bobot badan 181,66 $\pm 8,12 \mathrm{~kg}, 259,16 \pm 2,56 \mathrm{~kg}$, dan $355,83 \pm 8,12 \mathrm{~kg}$. Kandungan nutrisi ransum kontrol adalah protein kasar 8,82\% dan TDN $61,62 \%$. Perlakuan yang diberikan berupa ransum kontrol $+0 \%$ tepung kunyit $(\mathrm{T} 0)$, ransum kontrol $+0,5 \%$ tepung kunyit (T1), dan ransum kontrol $+1 \%$ tepung kunyit (T2). Penelitian dilakukan selama 35 hari yaitu 7 hari periode adaptasi pakan dan 28 hari periode perlakuan. Penambahan tepung kunyit (Curcuma longa) pada pakan sapi Peranakan Ongole hingga 1\% tidak berpengaruh signifikan $(\mathrm{P}>0,05)$ terhadap konsumsi bahan kering, akan tetapi berpengaruh signifikan $(\mathrm{P}<0,05)$ terhadap pertambahan bobot badan harian dan konversi pakan. Penambahan tepung kunyit level $1 \%$ bahan kering menunjukkan hasil terbaik terhadap pertambahan bobot badan harian dan konversi pakan.
\end{abstract}

Kata kunci: kunyit, feed aditif alami, sapi peranakan Ongole, produktivitas

\section{ABSTRACT}

The experiment aimed to evaluate the adduction of turmeric flour in the ratio on the productivity of Ongole cross cattle. The purpose of the study was to evaluate the effect of turmeric flour in the ratio on dry matter consumption, daily gain, and feed conversion ratio of Ongole cross cattle. The study was done at PGS Joe Cipir Jati Indah Village, Tanjung Bintang District, South Lampung Regency. The Study used 9 Ongole Cross Cattle males, divided into three groups according to the average body weight of 181,66 8,12 $\mathrm{kg}, 259,16 \pm 2,56 \mathrm{~kg}$, and $355,83 \pm 8,12 \mathrm{~kg}$ with randomized block design with three treatments and three groups. The control ratio was containing $8.82 \%$ crude protein and $61,62 \%$ TDN. They were fed a rations with control rations $+0 \%$ turmeric flour (T0), control ration $+0.5 \%$ turmeric flour (T1) and control ration $+3 \%$ turmeric flour (T2). The study was conducted for five weeks, one week of adaptation, and four weeks of data collection. The results of the study showed that the addition of $1 \%$ of turmeric flour had a significant effect $(P<0.05)$ on daily body weight gain and feed conversion ratio but had no significant effect $(P>0,05)$ on dry matter consumption. The addition of $1 \%$ of turmeric flour had a significant effect $(P<0.05)$ on daily body weight gain and feed conversion ratio but had no significant effect $(P>0,05)$ on dry matter consumption. The addition of $1 \%$ turmeric flour showed the best daily weight gain and feed conversion ratio.

Keywords: turmeric, botany feed additive, Ongole Cross Cattle, productivity 


\section{PENDAHULUAN}

Seiring dengan peningkatan jumlah penduduk dan kesejahteraan perekonomian masyarakat, konsumsi protein hewani semakin meningkat. Total konsumsi daging sapi di Indonesia tahun 2018 sebesar 124,292 juta ton, dan tidak diimbangi dengan produksinya sebesar 4,779 juta ton (Dirjen PKH Kementan, 2019). Kekurangan daging tersebut dipenuhi dari impor sapi dan daging beku dari luar negeri. Dalam rangka mengurangi jumlah impor sapi dan daging dengan upaya peningkatan produktivitas sapi potong lokal dengan perbaikan kualitas pakan. Sapi peranakan Ongole banyak dipelihara oleh peternak rakyat karena merupakan sapi lokal asli Indonesia yang memiliki kemampuan adaptasi terhadap lingkungan yang sangat baik (Menteri Pertanian Republik Indonesia, 2012). Peternak biasanya memanfaatkan limbah pertanian, perkebunan dan industri sebagai bahan pakan penyusun ransum karena harganya terjangkau. Rendahnya kualitas nutrien pada bahan pakan limbah pertanian menyebabkan produktivitas ternak tidak optimal.

Penambahan rimpang atau bahan herbal seperti temulawak, kunyit dan jahe sebagai pakan aditif alami dapat dilakukan untuk upaya peningkatan produktivitas sapi pedaging. Wati dan Yusuf (2019) menyatakan bahwa penambahan tepung temulawak hingga level 3\% dari bahan kering pakan memberikan pengaruh positif terhadap produktivitas Sapi Peranakan Simmental. Rimpangrimpangan merupakan alternatif pakan aditif alami yang diberikan untuk meningkatkan konsumsi pakan dan status kesehatan ternak sehingga diharapkan produktivitas ternak meningkat. Penggunaan pakan aditif alami bagi ternak lebih dianjurkan karena harga yang terjangkau, mudah diperoleh dan tidak akan meninggalkan residu pada produk ternak sehingga menghasilkan produk ternak yang sehat.

Kunyit (Curcuma longa) adalah jenis tanaman rimpang yang banyak dimanfaatkan sebagai antibiotik, antivirus, antioksidan dan memperbaiki saluran pencernaan (Shan dan Iskandar, 2018). Kunyit memiliki kandungan atsiri berkisar 2,5-6\% dan kandungan kurkuminoid sebesar 3-5\%, sehingga bersifat anti oksidan dan memperbaiki pencernaan (Hartati, 2013). Enzim-enzim pencernaan yang terkandung di dalam cairan empedu dan getah pankreas disekresikan oleh dinding kantong empedu yang dirangsang oleh kandungan kurkumin dalam kunyit. Minyak atsiri dalam kunyit membantu mempercepat laju pencernaan dalam lambung sehingga ternak akan cepat merasa lapar dan akan makan lebih banyak dan mengakibatkan pertambahan bobot badan ternak meningkat. Penambahan tepung kunyit $0,5 \%$ dari bahan kering ransum domba jantan lokal cenderung menghasilkan pertambahan bobot badan paling baik daripada domba yang diberi tepung kunyit pada dosis $0,75 \%, 1 \%$, dan tanpa pemberian tepung kunyit, namun belum memberikan pengaruh nyata terhadap konversi pakan (Prasetiadi et al., 2017).

Kurangnya informasitentang pemberian tepung kunyit pada sapi mendorong adanya penelitian untuk mengevaluasi pengaruh pemberian tepung kunyit pada ransum sebagai pakan tambahan alami terhadap produktivitas Sapi Peranakan Ongole.

\section{METODE}

Penelitian dilaksanakan di PGS. Joe Cipir Desa Jati Indah, Kecamatan Tanjung Bintang, Kabupaten Lampung Selatan. Sembilan ekor sapi peranakan Ongole jantan berumur \pm 2 tahun yang dikelompokkan menjadi 3 kelompok berdasarkan bobot badan. Sapi diberikan perlakuan ransum kontrol ditambah $0 \% ; 0,5 \%$, dan $1 \%$ tepung kunyit dalam bahan kering. Rancangan statistik yang digunakan yaitu Rancangan Acak Kelompok dengan 3 perlakuan dan 3 kelompok yaitu sapi dengan bobot badan $181,66 \pm 8,12 \mathrm{~kg}$, $259,16 \pm 2,56 \mathrm{~kg}$, dan $355,83 \pm 8,12 \mathrm{~kg}$.

Susunan formulasi ransum dan 
Tabel 1. Formulasi dan Kandungan Nutrien Ransum Kontrol

\begin{tabular}{|c|c|c|}
\hline No. & Bahan Pakan & Komponen Ransum (\%) \\
\hline 1. & Janggel jagung & 18 \\
\hline 2. & Onggok & 19 \\
\hline 3. & Bungkil sawit & 20 \\
\hline 4. & Kulit Kedelai & 10 \\
\hline 5 & Dedak & 20 \\
\hline 6 & Tetes & 5 \\
\hline 7 & Kulit Kopi & 8 \\
\hline Tota & & 100 \\
\hline \multicolumn{3}{|c|}{ Kandungan Nutrien Ransum: } \\
\hline \multicolumn{2}{|c|}{ Protein Kasar } & 8,82 \\
\hline \multicolumn{2}{|c|}{ TDN } & 61,62 \\
\hline
\end{tabular}

Keterangan: TDN $=$ Total Digestible Nutrient

kandungan nutrisi ransum kontrol tersaji dalam Tabel. 1

Penelitian didahului dengan persiapan kandang,peralatan kandang, bahan pakan dan analisis proksimat sebagai untuk mengetahui kandungan nutrien ransum kontrol. Periode adaptasi dilakukan selama 7 hari dengan memberikan ransum kontrol pada sapi untuk mengevaluasi konsumsi harian. Berdasarkan Peraturan Menteri Pertanian Republik Indonesia No.46 Tahun 2015, ransum dalam bahan kering diberikan sebesar $2 \%$ dari BB sapi. Frekuensi pemberian ransum dalam sehari sebanyak 2 kali yaitu jam 07.00 WIB dan jam 16.00 WIB. Pemberian air minum secara adlibitum. Penimbangan bobot badan awal sapi dilakukan pada pagi hari saat hari pertama perlakuan. Periode pengambilan data dilakukan selama 28 hari dengan memberikan ransum perlakuan pada sapi sesuai dengan kelompok. Perhitungan konsumsi bahan kering dengan cara menghitung selisih pemberian pakan harian dengan sisa pakan harian dalam bahan kering. Sampel sisa pakan dikumpulkan setiap hari dan diambil sampel untuk analisa kadar air. Pertambahan bobot badan harian sapi dapat dihitung dari hasil pengurangan bobot akhir dengan bobot awal pengamatan dibagi lama hari perlakuan. Bobot badan akhir sapi diperoleh dari hasil penimbangan sapi pada hari ke-29 setelah perlakuan. Besarnya konversi pakan dihitung dari jumlah pakan harian dibagi pertambahan bobot badan harian.

Data yang diperoleh diolah dengan Uji Anova dan dilanjutkan dengan Uji Jarak Berganda Duncan pada taraf 5\% jika terdapat pengaruh yang signifikan $(\mathrm{P}<0,05)$ (Steel dan Torrie, 1995).

\section{HASIL DAN PEMBAHASAN}

\section{Penambahan Tepung Kunyit (Curcuma longa) terhadap Produktivitas Sapi}

Pemberian tepung kunyit pada ransum sapi hingga level $1 \%$ tidak berpengaruh signifikan $(\mathrm{P}>0,05)$ terhadap konsumsi bahan kering tetapi berpengaruh signifikan $(\mathrm{P}<0,05)$ terhadap pertambahan bobot badan harian dan konversi pakan. Data pengaruh penambahan tepung kunyit (Curcuma longa) terhadap produktivitas sapi Peranakan Ongole tersaji pada Tabel 2.

Besarnya konsumsi bahan kering pada sapi T0, T1, dan T2 tidak berbeda nyata $(\mathrm{P}>0,05)$ berturut-turut sebesar 4.516,00 gram, 4735,48 gram dan 4368,80 gram. Besarnya konsumsi bahan kering sudah memenuhi kebutuhan bahan kering untuk sapi yaitu 
Tabel 2. Pengaruh Perlakuan Terhadap Produktivitas Sapi Peranakan Ongole

\begin{tabular}{lcccc}
\hline \multirow{2}{*}{ Variabel } & \multicolumn{3}{c}{ Perlakuan } & \multirow{2}{*}{ SD } \\
\cline { 2 - 4 } & T0 & T1 & T2 & \\
\hline Konsumsi BK (gram/ekor/hari) & 4516,00 & 4735,48 & 4368,80 & 108,17 \\
PBBH (gram/ekor) & $843,24^{\mathrm{b}}$ & $826,92^{\mathrm{b}}$ & $933,57^{\mathrm{a}}$ & 20,25 \\
Konversi Pakan & $10,52^{\mathrm{a}}$ & $11,32^{\mathrm{a}}$ & $9,16^{\mathrm{b}}$ & 0,331 \\
\hline
\end{tabular}

Keterangan: $\mathrm{BK}=$ Bahan Kering, $\mathrm{PBBH}=$ Pertambahan bobot badan harian, Huruf superskript menandakan berbeda nyata, huruf kecil $\mathrm{P}<0,05$

rata-rata sebesar $1,7 \%$ dari bobot badan sapi (Permentan No. 46, 2015). Kandungan nutrien ransum perlakuan yang sama menyebabkan besarnya konsumsi bahan kering tidak berbeda nyata. Mallidadi et al. (2019) menyatakan bahwa rasa, bentuk, tekstur dan kandungan nutrisi dalam pakan sangat berpengaruh terhadap konsumsi pakan. Vorlaphim et al. (2011) menyatakan bahwa penambahan ekstrak curcumin hingga $0,2 \%$ bahan kering dalam konsentrat sapi Brahman Cross tidak berpengaruh nyata terhadap konsumsi bahan kering, namun dapat berpengaruh positif dalam metabolisme nitrogen. Jaguezeski et al. (2018) menambahkan bahwa penambahan tepung ekstrak kunyit $100 \mathrm{mg} / \mathrm{kg}$ pakan domba Lacaune pada periode laktasi, tidak menunjukkan perbedaan nyata terhadap jumlah konsumsi bahan kering dibandingkan dengan domba yang diberi pakan tanpa tambahan ekstrak tepung kunyit namun dapat mengurangi stess oksidatif pada periode laktasi.

Rata-rata pertambahan bobot badan harian dan konversi pakan Sapi Peranakan Ongole yang diberi tepung kunyit hingga level 1\% (T2) pada pakan berbeda signifikan $(\mathrm{P}<0,05)$ dengan T0 dan T1. Pertambahan bobot badan harian sapi T2 sebesar 933,57 gram signifikan lebih tinggi $(\mathrm{P}<0,05)$ daripada sapi T0 sebesar 843,24 gram dan T1 826,92 gram, namun $\mathrm{PBBH}$ sapi T0 dan T1 secara signifikan tidak berbeda $(\mathrm{P}>0,05)$. Besarnya konversi pakan sapi T2 sebesar 9,16 nyata lebih rendah $(\mathrm{P}<0,05)$ daripada $\mathrm{T} 0$ yaitu sebesar 10,52 dan $\mathrm{T} 1$ sebesar 11,32, tetapi besarnya konversi pakan sapi T0 dan T1 tidak berbeda nyata. Besarnya PBBH dan konversi pakan pada sapi T2 nyata lebih baik daripada T1 dan T0 diduga disebabkan oleh kecernaan pada sapi T2 yang lebih tinggi. Nusi et al. (2011) menjelaskan bahwa kecernaan pakan dan kecukupan kebutuhan nutrien dalam tubuh ternak sangat berpengaruh terhadap besarnya konversi pakan. Hal ini memperkuat dugaan bahwa kandungan kurkumin dan atsiri dalam tepung kunyit yang dapat meningkatkan kecernaan nutrien dalam saluran pencernaan sapi. Kandungan kurkumin dan atsiri dalam tepung kunyit juga berfungsi sebagai antiprotozoa yang dapat menekan jumlah protozoa di dalam rumen sehingga dapat meningkatkan kecernaan nutrien pakan di dalam rumen (Li et al., 2011). Suharti et al. (2009) menyatakan bahwa jumlah populasi protozoa dalam rumen yang menurun dapat meningkatkan jumlah populasi bakteri sehingga terjadi pertambahan bobot badan ternak dan memperbaiki besarnya konversi pakan. Penambahan ekstrak kurkumin hingga $200 \mathrm{mg} / \mathrm{kg}$ pakan kambing Lacaune menunjukkan besarnya bobot badan dan pertambahan bobot badan yang lebih tinggi dibandingkan kambing yang tidak diberi tambahan kurkumin (Molosse et al. 2019). Budiari et al. (2020) menambahkan bahwa penambahan tepung kunyit hingga 1,5\% dari pakan konsentrat yang diberikan pada Sapi Bali dapat meningkatkan pertambahan bobot badan sebesar 38,24\% dan menurunkan konversi pakan sebesar $47,20 \%$.

\section{KESIMPULAN}

Penambahan tepung kunyit (Curcuma 
longa) hingga level $1 \%$ bahan kering memberikan pengaruh positif terhadap ratarata $\mathrm{PBBH}$ dan konversi pakan, namun tidak memberikan pengaruh terhadap konsumsi bahan kering. Penambahan tepung kunyit level $1 \%$ bahan kering menunjukkan hasil terbaik terhadap PBBH dan konversi pakan.

\section{DAFTAR PUSTAKA}

Budiari, N. L. G., Y. Pujiawati., I. N. Adijaya, dan I. P. A. Kertawirawan. 2020. Pengaruh Level Tepung Kunyit Pada Ransum Sapi Bali Terhadap Performans dan Pendapatan Peternak. Di dalam: Prospek Peternakan di Era Normal Baru Pasca Pandemi COVID-19. Prosiding Seminar Teknologi dan Agribisnis Peternakan VII-Webinar. 27 Juni 2020. Purwokerto. Fakultas Peternakan Jenderal Soedirman. 618-627.

Direktorat Jenderal Peternakan dan Kesehatan Hewan Kementerian Pertanian. 2019. Statistik Peternakan dan Kesehatan Hewan 2018. Direktorat Jenderal Peternakan dan Kesehatan Hewan Kementerian Pertanian, Jakarta.

Hartati, S. Y. 2013. Khasiat Kunyit Sebagai Obat Tradisional dan Manfaat Lainnya. Warta Penelitian dan Pengembangan Tanaman Industri. 19(2): 5-9.

Jaguezeski, A. M., G. Perin., N. B. Bottari., R. Wagner., M. B. Fagundes., M. R. C. Schetinger., V. M. Morsch., C. S. Stein., R. N. Moresco., D. A. Barreta., B. Danieli., R. C. Defiltro., A. L. B. Schogor, and A. S. D. Silva. 2018. Addition of curcumin to the diet of dairy sheep improves health, performance and milk quality. Animal Feed Science and Technology. 246(2018): 144-157.

Li, M., W. Yuan., G. Deng., P. Wang., P. Yang, and B. B. Anggarwal. 2011. Chemical Composition and Product Quality Control of Turmeric (Curcuma longa). Pharmaceutical Crops.5(1): 28-54.

Mallidadi, H., T.T. Nikolaus, dan L. S.
Enawati. 2019. Pengaruh Level Serat Terhadap Konsumsi dan Kecernaan Nutrien Sapi Varian Genetik dan Sapi Bali Normal. Jurnal Peternakan Lahan Kering. 1(3): 410-416.

Molosse, V., C. F. Souza., M. D. Baldissera., P. Glombowsky., G. Campigotto., C. J. Cazaratto., L. M. Steffani, and A. S. da Silva. 2019. Diet suplemented with curcumin for nursing lambs improves animal growth, energetic metabolism, and performance of the antioxidant and immune systems. Small Ruminant Resesarch. 170: 74-81.

Nusi, M., R. Utomo, dan Soeparno. 2011. Pengaruh penggunaan tongkol jagung dalam complete feed dan suplementasi undegraded protein terhadap pertambahan bobot badan dan kualitas daging pada sapi peranakan ongole. Buletin Peternakan. 35(3): 173-181.

Menteri Pertanian Republik Indonesia. 2012. Keputusan Menteri Pertanian No. 2841/Kpts/LB.430/8/2012 Tentang Penetapan Rumpun Sapi Peranakan Ongole. Kementerian Pertanian Republik Indonesia, Jakarta.

Menteri Pertanian Republik Indonesia. 2015. Peraturan Menteri Pertanian Republik Indonesia No. 046/Permentan/ PK210/8/2015 Tentang Pedoman Budidaya Sapi Potong Yang Baik. Kementerian Pertanian Republik Indonesia, Jakarta.

Prasetiadi, R., D. Heriyadi, dan Y. Yurmiati. 2017. Performa Domba Lokal Jantan Yang Diberikan Tambahan Tepung Kunyit (Curcuma domestica Val.). Jurnal Ilmu Ternak. 17(1): 54-57.

Shan, C. Y., dan Y. Iskandar. 2018. Studi Kandungan Kimia Dan Aktivitas Farmakologi Tanaman Kunyit (Curcuma longa L.). Farmaka Suplemen. 16(2): 548-553.

Steel, R.G.D. dan J.H. Torrie. 1995. Prinsip dan Prosedur Statistika Suatu Pendekatan Biometrik. Cetakan ke-4. 
PT. Gramedia Pustaka Utama, Jakarta. (Diterjemahkan oleh B. Sumantri).

Suharti, S., D. A. Astuti dan E. Wina. 2009. Kecernaan Nutrien dan Performa Produksi Sapi Potong Peranakan Ongole (PO) yang Diberi Tepung Lerak (Sapindus rarak) dalam Ransum. Jurnal Ilmu Ternak dan Veteriner. 14(3): 200207.

Vorlaphim, T., M. Phonvisay., J. Khotsakdee., K. Vasupen., S. Bureenok., S. Wongsuthavas., A. Alhaidary., H. E. Mohamed., A. C. Beynen dan C. Yuangklang. 2011. Influence of Dietary Curcumin on Rumen Fermentation,
Macronutrient Digestion and Nitrogen Balance in Beef Cattle. American Journal of Agricultural and Biological Sciences 6(1):7-11.

Wati, N. E. dan M. Yusuf. 2019. Peningkatan Produktivitas Sapi Peranakan Simmental dengan Penambahan Tepung Temulawak (Curcuma xanthorhiza) sebagai Pakan Aditif Alami. Prosiding Seminar Nasional Teknologi Peternakan dan Veteriner 2019. 15-16 Oktober 2019. Jember. Pusat Penelitian dan Pengembangan Peternakan, Kementerian Pertanian. 165-170. 